10. Cherniovanenko, A. (2002). The texture of the visazhalnny virazhalnyh authorities of bayan music: candidate's thesis. Kiev: NMAU P. I. Tchaikovsky [in Ukrainian]

11. Yareshko, A. (2005). Russian Bell Bells in the Synthesis of the Temple Arts: History, Styles, Functionality: Extended abstract of Doctor's thesis. Moscow: RAM Gnessins. Moskava [in Russian]

Стаття надійция до редакції 19.04.2017

УДК 78.03(78)

\author{
Тетяна Ігорівна Чабан \\ асистент-стажист кафедри спеціального фортепіано \\ Одеської національної музичної академії імені А. В. Нежданової \\ tanyaha@ukr.net

\section{ІМПРЕСІОНІСТИЧНО-СИМВОЛІСТСЬКІ ОЗДОБИ СОНАТИНИ МИКОЛИ КОЛЕССИ}

\begin{abstract}
Мета роботи. Стаття присвячена виявленню імпресіоністичносимволістських оздоб у творчості Миколи Колесси, які є реакцією автора на «виклик часу», «дух часу». Методологія спирається на сукупність методів: стильово-компаративний, культурологічний, герменевтичний. Наукова новизна визначається оригінальністю теоретичної ідеї, акцентування в спадщині названого автора, довіри до стилістичних показників імпресіонізму-символізму і через них «м'якого» неокласицизму, а також самостійністю аналізу у названому ракурсі вказаної сонатини. Висновок. Сонатина є яскравим взірцем поєднання досягнень народного та професійного мистецтва, адже в ній поєднались не лише риси модерну, але й західноукраӥнський фольклор. Композитор майстерно поєднує у своїй творчості прийоми музичного імпресіонізму-символізму з фольклорною автентичністю тематизму, не застосовуючи при цьому uитатат.
\end{abstract}

Ключові слова: імпресіонізм, символізм, оздоби, «м'який» неокласицизм, сонатина.

Chaban Tetyana, assistant-trainee of the department of special fortepiano the Odessa national A. V. Nezhdanova academy of music

Impressionist-symbolist decorations of Sonatina Mykola Kolessa

The work objective. The paper is devoted to the disclosure of impressionist-symbolist decoratiosn in the works of Mykola Kolessa, which represent the response of the author to the «the call of time», «the spirit of times». Methodology

(C) Чабан T. I., 2017 
relies on the complex of methods as follows: stylistic comparative, cultorological and hermeneutic. The scientific novelty is defined by the originality of theoretical idea, accentuation in the heritage of the mentioned above author, trust inthe stylistical characteristics of impressionism-symbolism and through their «tender» Neoclassicism, as well as independency of analysis in the mentioned aspect of the given sonatina. Conclusion. Sonatina is an outstanding example of combination of the achievements of popular and professional art, since it combined both features of modernist style and the West Ukrainian folklore. The composer skillfully combines in his works techniques of musical impressionism-symbolism with the folklore thematic invention authenticity, without using the quotations.

Keywords: impressionism, symbolism, decorations, «tender» Neoclassicism, sonatina.

Чабан Татьяна Игоревна, ассистент-стажер кафедры специального фортепиано Одесской национальной академии имени А. В. Неждановой

Импрессионистично-символистские украшения Сонатины Николая Колессы

Цель работы. Статья посвящена выявлению импрессионистских-символистских украшений в творчестве Николая Колессы, которые являются реакиией автора на «зов времени», «дух времени». Методология опирается на совокупность методов: стилистически-компаративный, культурологический, герменевтический. Научная новизна определяется оригинальностью теоретической идеи, акцентированием в наследии названного автоpa, доверием к стилистическим показателям импрессионизма-символизма и через них «мягкого» неоклассицизма, а также самостоятельностью анализа в названном ракурсе указанной сонатины. Вывод. Сонатина является ярким образцом сочетания достижений народного и профессионального искусства, ведь в ней соединились не только черты модерна, но и западноукраинский фольклор. Композитор мастерски сочетает в своем творчестве приемы музыкального импрессионизма-символизма с фольклорной аутентичностью тематизма, не применяя при этом цитат.

Ключевые слова: импрессионизм, символизм, украшения, «мягкий» неоклассицизм, сонатина.

Актуальність дослідження визначає творча постать Миколи Колесси, який в своїй творчості оспівував національні ідеї, традиціоналізм західноукраїнського регіону. Хоча за свідоцтвом сучасників і в самохарактеристиках композитора звучали посилання на Равеля, імпресіонізм. Саме ці риси вказували на реакцію Колесси на «поклик часу», «духу часу» за Гегелем, що само собою підкреслювало високу постать західно-українського митця.

Метою роботи виступає дослідження імпресіоністично-символістських елементів в стилістиці автора і через них втілення «м'яких» 
контурів неокласицизму, які органічно увібрав Равель, і які притаманні українському майстру.

\section{Завдання роботи}

1. Висвітлити матеріали, які вказують на готовність Миколи Колесси до входження в коло модереністичних винаходів XX століття, як атрибутів мислення часу.

2. Аналіз сонатини М. Колесси у співвіднесеності зі зразками фортепіанних творів М. Равеля і тих, що оживили названого французького творця.

Методологічна основа спирається на сукупність методів: стильовокомпаративний, культурологічний, герменевтичний. Особливе значення в цьому плані мають розробки Б. В. Жаркової, О. М. Ступеля та інших. Об'єкт дослідження: ознаки стильових «викликів часу» в спадщині М. Колесси. Предмет усвідомлення відкритості до модерну при усвідомлені турботи щодо фольклорно-національної визначеності музичного виразу.

Наукова новизна визначається оригінальністю теоретичної ідеї, акцентуванням в спадщині названого автора довіри до стилістичних показників імпресіонізму-символізму і через них «м'якого» неокласицизму, а також самостійністю аналізу у названому ракурсі вказаної сонатини.

Творча постать М. Колесси репрезентує кращі традиції національної композиторської школи. Його доробок загалом представляє собою пізньоромантичну, за висловленням КальмучинДранчука Т. «трохи модернізовану традицію в іiі національній інтерпретації» $[6,76]$. Такий підхід є закономірним, оскільки творчі здобутки М. Колесси в сфері фортепіанної музики виявляють природній синтез модерних тенденцій європейського мистецтва $30-\mathrm{x}$ років із глибинним переосмисленням етнографічної традиції. Але подання цього модерністичного спрямування лише в ракурсі «пізнього романтизму» явно звужує стильові тяжіння автора. Недаремно Василь Барвінський одним із перших охарактеризував М. Колессу справжнім новатором, першим українським імпресіоністом $[6,76]$. Важливою рисою стилістики М. Колесси є конкретна програмно-жанрова ідея. Домінуючі засоби виразовості, якими оперує композитор, це: гуцульський, дорійський, фрігійський лади, двічі гармонічний мінор, гостра синкопована артикуляція, безперервна мелодична, динамічна варіаційність тематизму, який складається 3 лаконічних мотивів. 
Сама назва жанрового різновиду розглядуваного твору К. «Сонатина» виводить на аналогію до відповідного типологічного рішення M. Равеля («Сонатина» fis-moll). Могутня фольклорна спрямованість мислення Колесси співвідносна з фольклористичними виходами французького метра, для якого, правда, національний фольклорний елемент безпосередньо не «світився» в його композиціях, тоді як звернення до іспанського, грецького, німецького, російського та інших етнічно-національних показників, які символізували артистичну надмірність французького способу художнього мислення. Багатогранна трансформація тих впливів визначає мистецьку цінність фортепіанної композиції М. Колесси [6, 76].

Взаємодія з фольклорними елементами відбувається на всіх рівнях музичного твору: образно-емоційному, семантичному, мовностилістичному, конструктивному. В процесі аналізу підкреслюється контактність співвіднесеності композиційного рішення з сонатамисюїтами рококо, в яких варіантність викладення тематизму у сумісництві з різними архітектонічними тенденціями забезпечувала спирання на фольклорні витоки їх творчості. Композитор майстерно поєднує у своїй творчості прийоми музичного імпресіонізму-символізму з фольклорною автентичністю тематизму, не застосовуючи при цьому цитат (що знов вводить аналогію до французької школи).

М. Колесса написав для фортепіано не так вже й багато творів, більшість з яких створена у тридцяті роки: цикл мініатюр «Дрібнички», сонатину «Слідами Довбуша», сюїту «Картини Гуцульщини», «Фантастичний прелюд». П'єси для дітей, «Осінній прелюд», прелюди «Гуцульський», «Про Довбуша» були написані пізніше. Як видно, здебільшого автор прагне конкретизувати свій задум за допомогою словесних програмних уточнень, використовуючи їх винахідливо і розмаїто. Звертає на себе увагу зосередження на постаті Довбуша, яка символізує для Західної України національного героя. Довбуш уособлює в собі ідею багатовікової боротьби за незалежність.

Але у цілому вказані програмні заголовки надто узагальнено (порівняно з романтичними літературними описами) подають образноподійові ознаки, що підводить їх до пограниччя символістської «недомовленості». Відзначені вище звертання до французького джерела немов підкреслюються значущістю жанру прелюда, що займає самостійне місце саме у французькому інструменталізмі.

Звертаємо увагу на той факт, що відзначені повороти М. Колеси до модерністських рис вираження складалися у 1930-ті роки, тобто 
в період «традиціоналізації у цілому стильових тяжінь мистецтва див. принциповий поворот до неокласицизму й симфонізму у вказані роки таких відвертих послідовників ідей модерну-авангарду як члени Шістки. «Приглушеність» відзначених модерністичних торкань у М. Колеси, таким чином, є також свідоцтвом його чутливості до «ідей часу», оскільки гострота подання модерну-авангарду спостерігається у 1910-1920-ті, 1950-1960-ті роки, тоді як 1930-1940-ві об'єктивно постають періодом злету таких традиційних жанрів як симфонія, опера повнооб'ємного типу, що не є показовим для «хвиль авангарду» у згадані десятиріччя.

Сонатина для фортепіано М. Колесси, написана в 1939 р., втілила в собі зовсім нову особливість, яка не була характерна для української музики: це органічне поєднання національно-характерного мелосу карпатського типу з сонатною формою. Тут вперше синтезувалися провідні стильові тенденції XX ст. - неокласицизм, імпресіонізм та неофольклоризм. Це відбилося у характері музичного матеріалу, що увібрав в себе ритмо-інтонаційні та структурні ознаки фольклору карпатського регіону, при тому, як було відзначено, автором цитати не вживаються. Останнє наближує до неофольклорних «подихів» Б. Бартока, хоча безумовною перевагою для М. Колесси був неокласичний нахил спілкування з неофольклоризмом.

Привертає увагу дуже конкретний і аналітичний тон, яким композитор говорить про свій твір: «...фортепіанна Сонатина, яку написав у 1939 р., звісно, на мене мали вплив і твори того ж жанру Моріса Равеля, і сонатини мого вчителя Новака, але я прагнув передати в ній насамперед національні образи, навіяні фольклором, нашим епосом, легендами. Тому частини Сонатини і мають програмні назви, пов'язані з легендарним образом Довбуша, дуже популярним в нашому мистецтві: «Слідами Довбуша», «Довбуш і Дзвінка», «Біля вогнища». Хоча сама програма є досить умовною, вона має на меті лише окреслити головні настрої і картини, які я прагнув передати в цьому творі» $[2,88$.$] . Подана цитата цікава також тим, що в ній композитор$ ще раз прямо вказує на вплив Равеля на свою фортепіанну Сонатину.

Але маємо підкреслити, що відзначений «равелізм» Колесси чітко корегується моцартіанськими посиланнями і в моцартіанських же вимірах (і з елементами рококо!), подані «натяки на Шопена». Саме початок Сонатини Колесси 3 фактурою «романса-аріозо без слів» вводить алюзію до знаменитої Сонати a-moll K № 310 В. Моцарта. Вказана паралель Моцарт - Колесса усвідомлюється наявністю 
«моцартівського міні-кластеру» у вигляді позаакордової ноти (даної форшлагом) у тонічному тризвуку (вертикаль $\mathrm{a}-\mathrm{c}^{1}-\mathrm{e}^{1}-\mathrm{h}^{1}-$ див. a-c $\mathrm{c}^{1}$ $\mathrm{e}^{1}$-dis² у Моцарта).

Щодо паралелей до Шопена, то звертаємося до конструкцій сонатних Allegro у польського композитора, де розробка широко показує головну партію, а реприза «задовольняється» однією побічною (див. I частину Другої сонати Ф. Шопена) або починається з побічної, даючи «дзеркальну» репризу (див. Allegro Першої Балади Шопена). Але загалом багатство романтичної фактури польського майстра Колесса ніяк не відображує. I тричастинна композиція Сонатини не збігається з принциповим монуменнталізмом шопенівської сонатної чотирьохчастинності.

Образи «Сонатини» є відвертими та щирими у втіленні синтезу європейського клавірно-фортепіанного фактурного надбання і національно-фольклорних моментів. Відзначені вище ладові побудови: гуцульський, дорійський, фрігійський лади, двічі гармонічний мінор, дійсно показові для фольклорного гуцульського вжитку 一 але подібне знаходимо і на європейському Півдні, і у Скандинавії (див. геніальну «симуляцію фольклоризму» у Я. Сибеліуса та ін.). Вказане поєднання певних європейських і специфічно гуцульських фольклорних елементів торкається і мелізматичного ряду тем Сонатини, оскільки органіка його для співочої Гуцульщини не менша, ніж мелізматичний «фльор» рококо. I це закономірно, бо витоком і для першого, і для другого була фігуративність староцерковного співу, похідного від візантійських джерел: і для України, і для Франції дане джерело було і залишається актуальним в стимуляції національних пошуків виразності музики.

Лінія музично-драматургічного розвитку класично вибудована i послідовно логічна. Але навмисно підкресленою виступає жорстка монотематична вибудованість усіх тем твору. Так, якщо у головній партії I частини квартовий хід є стрижньовим, але істотно його ж доповнює квінтовим форшлагом даний тон (вертикаль $\left.\mathrm{a}-\mathrm{c}^{1}-\mathrm{e}^{1}-\mathrm{h}^{1}\right)$, то у побічній Allegro заповнення пощабельного квінтового обсягу складає суть мелодичної побудови. А щодо фактурного вирішення обох тем, то вони принципово подібні: «аріозо-романс без слів». Квінтовоквартовиий хід відзначає основну тему II частини. I подібна ж інтервальна завантаженість відзначає провідний тематизм Фіналу.

Так впізнаємо quasi-серійні показники тематичних компонентів, що нагадують відповідні ознаки тематизму циклів французьких кла- 
весиністів XVIII сторіччя, які відверто моделювали форми у К. Дебюссі і М. Равеля.

Істотну роль відіграє у Сонатині програмність, а вище відзначалася певна їі символічність, бо назви частин не мають літературно-сюжетної контактності. Кожна з частин має конкретну назву: перша частина — «Слідами Довбуша», друга - «Довбуш і Дзвінка», третя - «Біля вогнища». Звісно, це узагальнений тип програмності, він передбачає лише створення виразнішого фольклорного колориту. Звертаємо увагу на прелюдійний характер назви I частини («Слідами Довбуша»), де відсутня постать названого у заголовку персонажа. За назвою - це легенда про Довбуша в пам'яті людей. I втім характерні коломийкові звороти, домінування гуцульського ладу в ладотональній палітрі в поєднанні з прозорою фактурою $і$ відвертими рисами моцартіанського рококо $[14,155]$ - дають ємний образ значущості, національного шанування з посиланнями на сакралізовані культурним пієтетом зразки європейського світу. Вище відзначалися також посилання на неофольклоризм: теми Колесси збагачені ефектами підголоскового багатоголосся, породжують асоціації з неофольклористичними засадами стилю Б. Бартока, проте на українському народнопісенному грунті. Все це свідчить про співзвучність художніх пошуків М. Колесси до провідних естетичних установок свого часу [8, 293].

Особливостями цього твору можна вважати безконфліктну драматургію на рівні монотематичної поєднаності музики кожної частини зокрема та тричастинного циклу в цілому. Так вимальовується наближеність до специфіки монотематизму XX сторіччя, вибудованого на просерійних і саме серійних засадах, що народжує у фактурі постійні трансформації основних тематичних комплексів.

Перша частина (Allegro-moderato) легка і рухлива, розвивається дуже природно і невимушено. Тут оригінально поєдналися елементи гуцульського фольклору з класицистичними прийомами фортепіанного викладу. Її основна тема привертає увагу своєрідністю ладотональних поєднань мажоро-мінору та лідійського ладу, стриманою енергією, танцювальністю, що підкреслюється чіткою ритмікою та гомофонно-гармонічним складом фактури. У головній партії звучать три мотиви: фанфарний хід-заклик (такти 1-2), ліричний пісенний розділ (такти 3-5) та танцювальний (такти 6-9), що утворились 3 квартової поспівки, своєрідного «тематичного зерна», в тональності a-moll. Барвистість гуцульського ладу, його експресивність надзвичайно випукло виражені в головній темі першої 
частини фортепіанної Сонатини, в якій підкреслення четвертого підвищеного ступеня надає темі в цілому доволі конструктивній і лаконічній, неповторності.

Декілька варіантних проведень цієї теми, в яких вона обростає підголосками та змінює свій фонізм, створюють ефект барвистого «висвячування» початкової лаконічної теми. Побічна партія цієї частини не вносить істотного контрасту, це ще один аспект картинно-динамічного дійства, та все ж вона більш наспівна і ніжна, втілює почуття світлої радості, неодноразово забарвленої задумливо-меланхолійним настроєм. Спочатку мелодія цієї теми одноголосна, у другому проведенні вона написана в акордовому викладі.

У розробці Микола Колесса застосовує класичні прийоми розвитку - поглиблену сферу субдомінанти, імітаційне проведення мотивів головної партії. Спостерігається також тенденція до поступового стиснення мотивів, що надає розвитку більшої напруги. Уся розробка розвивається на динамічному зростанні з уточненням benritmico.

Особливістю цієї форми є дзеркальна реприза з проведенням побічної партії в тональності субдомінанти, а також ладове багатство тематизму. Ця частина витримана в єдиному емоційному рівні без особливо піднесених наростань і спадів, так, як це часто зустрічається в неокласицистичних творах (їх мета полягає не в тому, щоб вразити силою переживань, а швидше в тому, щоб захопити досконалістю і вишуканістю форм і ліній). Щодо твору М. Колесси - він повністю відповідає окресленій цілі [8, 294].

Друга частина — «Довбуш і Дзвінка» - має жанровий підзаголовок «Ноктюрн», що характеризує образну емоційність музики. Це ліричний центр циклу. Тут композитор засобами тонкого колористичного звукопису змальовує картину нічної природи, яка завдяки сильному ліричному струменю виходить за рамки звичайної пейзажності. В ній вишуканий імпресіоністичний колорит забарвлює національно характерні теми, які викликають асоціації з ліричними піснями-романсами. Лірико-споглядальний настрій втілений із граничною ясністю. Мелодія широкого дихання дублюється в мелодичній фігурації супроводу, обплітаючись делікатним візерунком, вишуканість гармонічної палітри створює ефект недомовленості, таємничості. У процесі розвитку тема набуває пристрасного, експресивного характеру, і в кульмінаційному розділі звучить навіть драматично.

Найбільш цікавим і своєрідним є фінал Сонатини — «Біля вогнища». В його основі лежить активна тема танцювального складу, побудована 
на ритмах і мотивах чоловічого гуцульського танцю - аркана, яка доповнюється контрастуючими епізодами. Мелодика грунтується на щедрих народних джерелах. Звідси композитор черпає ладогармонічний аромат, типи розвитку музичного матеріалу. Тема захоплює імпульсивністю руху, палким темпераментом і несподіваними ритмічними перебоями. В їі розвиток композитор вносить багато творчої винахідливості, створюючи барвисту картину народно-танцювальної сцени. Сама категорія стихійності в цій частині втілена так само стримано і конкретно, як і всі інші настрої. Нічим не затьмарена ясність авторської позиції ніби дозволяє спостерігати танцювальне дійство, захоплюючись яскравими барвами, відблисками ладотональної світлотіні.

Доволі яскравий контраст вносить «жіноча» тема, позначена авторською ремаркою dolce, та вона з'являється лише для того, щоб відтінити енергію і життествердність основного образу.

Закінчується Сонатина кодою (meno mosso). Незважаючи на акордовий виклад, тут зберігається танцювальний характер. Продовжується динамічне зростання, шо приводить до помпезного закінчення на $f f$ та pesante.

Сонатина, як і більшість творів М. Колесси, є багатотемною і приваблює емоційно щирим та дуже яскравим тематизмом. В одній мелодії відбувається зіставлення кількох індивідуалізованих тематичних елементів.

Стисла за формою, Сонатина є яскравим взірцем поєднання досягнень народного та професійного мистецтва. Складність іiі виконання - у поєднанні імпресіоністичного звукопису із національними особливостями тематичного матеріалу, що відповідає тенденціям клавіризації фортепіано, згідно з засадами французького піанізму. Останній мав особливу вагу для Колесси як львів'янина, тому шо Львівська консерваторія пишалася і пишається наявністю у складі професури у другій половині XIX сторіччя К. Мікулі, учня Ф. Шопена, який не відзивався на оркестралізацію фортепіанного мислення «за Лістом», підтримуючи «легку» манеру салонного піаністичного мистецтва Ф. Шопена. У творі М. Колесси відверто уникнути оркестральна щільність і розкиданість «поствіденської» фактури. I переконливо звучить в устах автора (див. висловлення Колесси щодо зв'язків з творами Равеля) посилання на вплив саме французьких фортепіанних здобутків на палітру його творчості. Надзвичайно важливим для виконавця є: осмислити усю витонченість, ясність, колосальне відчуття барви кожного звуку, регістро- 
вих переходів та гармонічних нюансів, які надважливі для створення цілісності образу твору.

Не менш істотною є роль ритміки, яка вельми своєрідно віддзеркалює гуцульський фольклор, з його пружним поступом, гострими і часто несподіваними акцентами, - а останні співвіднесені з «ритмікою пульсацій» стравиністського типу, на фоні якої «гра синкоп» втілює ритмічні узори як такі. Динаміка яскраво підкреслює клавесинну зверненість тематичного матеріалу, що виражається у відносності контрастів piano - forte, оскільки «по-клавесинному» ж відсутні виражені crescendo - diminuendo, демонструючи «терасну динаміку» (у паралель до відповідних динамічних ефектів у символіста О. Скрябіна).

Висновки. Підводячи підсумки аналізу Сонатини М. Колесси, особливо наполягаємо на делікатних формах входження в модернізм методом «оздоб» від символізму-імпресіонізму через згущення показників рококо у неокласичних рисах вибудови твору. Сучасність музики М. Колесси виражається в різновиді «спокійного» відтворення тенденцій модерну, але у явному відстороненні від відзначеної П. Муляром $[11,181]$ класичного - романтичного у стильових дихотоміях виконавських установлень.

Фортепіанна спадщина Миколи Колесси, створена протягом майже шістдесяти років - від кінця 20-х рр. до 80-х рр. ХХ ст. - стала без перебільшення знаковим явищем української музичної культури і втілила найяскравіші ознаки його індивідуального письма. Адже індивідуальний композиторський стиль М. Колесси, його світоглядні засади завжди відзначало прагнення до творення музики ясної, зрозумілої, легко сприймальної, та разом з тим не позбавленої художнього експерименту, пошуку нових форм і засобів музичної виразовості, барвистості палітри і дивовижного відчуття гармонічної колористики, що йде, безумовно, від закладеної в його мистецькій свідомості домінанти діяча національної культури пасіонарного типу, котрий мислить і себе і свою творчість невід’ємною часткою загальноєвропейської духовної традиції.

\section{СПИСОК ЛІТЕРАТУРИ}

1. Бермес І. В. Барвінський і М. Колесса. Молодь і ринок. 2009. № 3. С. $86-$ 90.

2. Білинська М. Роман Аполлонович Сімович. Українська радянська музика. Питання історії музики: зб. статей. 1962. Вип. 2. С. 87-92.

3. Бокщанина Е. История музыки народов СССР: до Великой Октябрьской социалистической революции: учебник для музыкальных вузов. Изд. 2-е, доп. М.: Музыка, 1978. 429 с. 
4. Горюхина Н. Эволюция сонатной формы. К.: Музична Україна, 1973. $308 \mathrm{c}$.

5. Дремлюга М. Українська фортепіанна музика (дожовтневий період). К.: Держ. вид. обр. мист., 1958. 167 с.

6. Кальмучин-Дранчук Т. Фортепіанна творчість М. Колесси в контексті проблеми виконавської інтерпретації. Вісник Прикарпатського університету. Мистецтвознавство. 2005. Вип. VIII. С. 73-80.

7. Кияновська Л. Соціокультурна парадигма львівської композиторської школи. Записки НТШ. Праці музикознавчої комісії. 2009. T. CCLVIII. C. 125134.

8. Кияновська Л. Стильова еволюція галицької музичної культури XIX ХХ ст.. Тернопіль: Астон, 2000. 339 с.

9. Крушельницька М. Стильові особливості виконання фортепіанних творів М. Колесси. Українська фортепіанна музика та виконавство: матеріали III конференції. К., 1994. С. 51-53.

10. Ланцута Л. Українська неоромантична фортепіанна соната. Записки Наукового товариства ім. Т. Шевченка. Праці Музикознавчої комісії. 1996. T. CXXXII. C. $165-179$.

11. Муляр П. М. Стиль твору і виконавської інтерпретації в аспекті взаємодії класичного та акласичного в фортепіанному мистецтві: дис. ... канд. мистецтвознавства: 17.00.03 / ОНМА імені А. В. Нежданової. Одеса, 2009. $181 \mathrm{c}$.

12. Ніколаєва Л. Фольклорні елементи в фортепіанній творчості М. Колесси: До 80-річчя з дня народження. Народна творчість та етнографія. 1983. № 6. С. $28-34$.

13. Стецюк Р. Віктор Косенко. К.: Музична Україна, 1974. 56 с.

14. Хіль О. Тема дитинства-юнацтва як фактор жанрової типології фортепіанного концерту в вітчизняній інструментальній музиці XX століття. дис. ...канд. мистецтвощнавства: 17.00.03 / ОНМА імені А. В. Нежданової. Одеса, 2015. $155 \mathrm{c}$.

\section{REFERENCES}

1. Bermes, I. (2009). Barvinsky and M. Kolessa. Molod' I rynok, 3, 86-90 [in Ukrainian].

2. Bilynska, M. (1962). Roman Apollonovich Simovich. Ukrainian Soviet music. Collection of articles, 2, 87-92 [in Ukrainian].

3. Bokschanina, E. (1978). History of music of the U. S.S. R. peoples: before the Great October Socialist Revolution. Moscov: Textbook for musical high schools [in Russian].

4. Horyukhina, N. (1973). Evolution of Sonata forms. Kyiv: Musical Ukraine [in Ukrainian].

5. Dremlyuga, M. (1958). Ukrainian pianoforte music (pre-October period). Kyiv: State Publishing House of Visual Art [in Ukrainian]. 
6. Kalmuchyn- Dranchuk, T. (2005) M. Kolessa's pianoforte work in the context of performance explication problem. Bulletin of the Precarpathian University. Art studies, Vol. VIII, 73-80 [in Ukrainian].

7. Kyyanovska, L. (2009). Sociocultural paradigm of Lviv school of composition. NTSh Notes: Proceedings of the musicological committee, Vol. CCLIII, 125-134 [in Ukrainian].

8. Kyyanovska, L. (2000). Style evolution of Galician musical culture of the 19th -20 th centuries. Ternopil: Aston, 339 [in Ukrainian].

9. Krushelnytska, M. (1994) Style features of performing pianoforte works of M. Kolessa. The Ukrainian pianoforte music and performing. Materials of the 3rd Conference, 51-53[in Ukrainian].

10. Lantsuta, L. (1996). The Ukrainian neo-romantic pianoforte sonata. The Works of Music Studies Commission, Vol. CCXXXII, 165-179 [in Ukrainian].

11. Mulyar, P. (2009). The style of the work and performing interpretation in terms of interaction and classical pianoforte art: Candidate's tesis. Odesa: ONMA named after A. V. Nezhdanova [in Ukrainian].

12. Nikolayeva, L. (1983). Folk elements in the pianoforte works of M. Kolessa [to the 80th anniversary of the birth]. mag.»Folk Art and Ethnography», No.6, 28-34 [in Ukrainian].

13. Stetsyuk, R. (1974). Viktor Kosenko. Kyiv: Musical Ukraine [in Ukrainian].

14. Khil, O. (2015). The theme of childhood, youth as a genre factor of typology of pianoforte concert in domestic instrumental music of the 20th century: dis. PHD. Odesa: ONMA named after A. V. Nezhdanova [in Ukrainian].

Стаття надійила до редакції 19.04.2017

УДК $78.083 / 78.03+781 / 784.3$

\author{
Лю Юйтен \\ здобувач кафедри історії музики \\ та музичної етнографіі \\ ОНМА ім. А. В. Нежданової \\ odma_n@ukr.net

\section{ЖАНРОВО-СТИЛЬОВА ДІАЛОГІЧНІСТЬ КАМЕРНО-ВОКАЛЬНОЇ ТВОРЧОСТІ ЯК ПРЕДМЕТ МУЗИКОЗНАВЧОГО ДИСКУРСУ}

Мета статті полягає у визначенні та розмежуванні жанрових та стильових критеріїв вивчення камерно-вокальної творчості, що сформовані у музикознавчих роботах останніх років, водночас у виявленні вихідної єдності - образно-естетичної інтегративності жанрово-стильової форми камерно-вокальної музики. Методологія роботи обумовлена 